\title{
A Brief Overview of the IPO Valuation Methods
}

\author{
Olga Ferraro $^{1}$ \\ ${ }^{1}$ Department of Business Administration, University of Calabria, Italy \\ Correspondence: Olga Ferraro, Department of Business Administration, University of Calabria, 87036, Arcavacata \\ di Rende (CS), Calabria, Italy. E-mail: olga.ferraro@unical.it
}

Received: October 14, 2020

Accepted: November 1, 2020

Online Published: November 6, 2020

doi:10.5539/ijbm.v15n12p41

URL: https://doi.org/10.5539/ijbm.v15n12p41

\begin{abstract}
The method adopted for pricing in an Initial Public Offering is a key issue in the studies on business valuation. In particular, various researches sought to verify which valuation methodologies are preferable in the context of an initial public offering.

The review of the main literature shows that Discounted Cash Flow, Market Multiples, Dividend Discount Model and, even if just to some degree, Economic Value Added are the most popular methodologies in the valuation practice.

The comparison among different valuation methods, proposed in the literature and variously applied in national and international practices, reveals the necessity to pay more attention to valuation mechanisms that drive the pricing of the shares to be listed.

The topic is linked to the ever more pertinent debate on the use of different methods in professional practice: financial experts and analysts tend, in fact, to compare results according to different estimates.
\end{abstract}

Keywords: company valuation, initial public offerings, evaluation methods

\section{Introduction}

As we know, the term Initial Public Offering (IPO) defines the offer aimed at raising capital on the equity market for a company not yet listed. It stands as one of the most important financial operations in the life of a company, as it could condition its entire life cycle; for this reason, it has attracted a great deal of interest in the business administration literature.

Amongst other things, the method or pricing an IPO stands as a top-level topic in the studies dedicated to business valuation. Pricing the shares of an IPO is a process that cannot be separated from business valuation, even if it has specific objectives and follows its own paths. As a matter of fact, like any valuation process, even the one concerning an IPO has to be addressed in a non-mechanical way and requires an adequate information base, typically represented by industrial plans and information on the business model, the positioning, the competitive advantages and the governance system of the company to be listed.

However, unlike in other processes, the elements that affect the pricing of the IPO can be numerous: the fundamental values of the company being listed; qualitative judgements (management, strategies, etc.); the use of an absolute or relative valuation method; the cyclical conditions of the capital market (in particular the stock market); the repercussions on the stock's secondary market; the occurrence of underpricing, the role and specific interests of the various involved parties (owners, sponsors, investors, etc.); and last but not least, the consequences on the image of the company and the sponsor. We should also mention the intensity of the demand during the placing phase, the final cost level of the placing, and other variables to be considered on a case-by-case basis.

To be able to approach the evaluation process in line with the PIV 1.4.3, all involved parties have to start from a fundamental analysis process than involves the consideration and evaluation of the relevant documentation and information, while selecting the most suitable methodologies for the purpose and assessing the main risk factors.

Amongst other things, the valuation of a company in the context of stock exchange listing is the result of a continuous process of analysis and verification which starts from a preliminary estimate of the value performed when all the data and information about the company are not yet available (the moment known as pitch) up to the pre-money pricing, when the share is actually sold to investors. 
The valuation process is progressively enriched in substance and content during the pre-listing stages when the company provides detailed data and information on the business and its future prospects. The valuation should be conducted by placing the emphasis on the industrial perspective and the search for business value: for these reasons, the industrial plan stands as the main tool on which the entire process is based.

The twofold objective of the present study derives precisely from these considerations. On one hand, it intends to investigate the most important aspects that characterize the process of evaluating and fixing the price of a company close to stock-exchange listing. On the other, it is set to analyse the main valuation methods adopted in practice to estimate the value of a company and, consequently, also the price of the shares it is about to issue.

To this end, the first part of the article is dedicated to the review of the most relevant studies in the business literature on the methodologies adopted in the context of IPOs; this is followed by an in-depth overview of the main methods adopted in practice to estimate the value of a company being listed and the price of its shares. The review focuses on pricing to take into account the fact that the value of a company could differ considerably during its transformation into a public company. Finally, the conclusions highlight the main critical issues resulting from the comparison of the adopted methods.

\section{Literature Review}

The results of the first relevant studies on the methods adopted to define the value of companies close to listing have shown that the banks involved in placing tend to prefer the multiples approach, thus ignoring those models based on cash flows (Block, 1999; Barker, 1999; Bradshaw ,2002; Demirakos et al., 2004; Asquith et al., 2005). According to these studies, in fact, the multiples approach provides ample room for manoeuvre to the intermediary, ensuring that the value of the issuer is in line with the target price defined in advance. In contrast, they highlight how the lesser popularity of techniques based on cash flows are attributable to the difficulty of projecting future flows and selecting an appropriate discount rate (Block, 1999; Bradshaw, 2002) or to the industry to which the company belongs. (Barker, 1999; Demirakos et al., 2004).

The preference for the multiples technique, with a major use of the $\mathrm{P} / \mathrm{E}$ ratio, is also reflected in the results of studies based on empirical evidences conducted on the most relevant valuation models adopted by professional investors and financial analysts (Govindarajan, 1980; Previts et al., 1994; Yap, 1997).

In contrast to the previous literature, Deloof et al. (2009), in a study conducted on the offer prices of 49 IPOs placed between 1993 and 2001 at Euronext in Brussels, show that the most popular method adopted by investment banks for estimating the offer price is the Discounted Cash Flow (DCF), followed by market multiples and the Dividend Discount Model (DDM). According to the authors, this result can be partly justified by the scarce number of comparable listed companies, but also by the fact that estimates made through the multiples approach would lead to a stock overestimate in the reference period of the sample. Furthermore, the examination shows that the underwriter to fix the Preliminary Offer Price (POP) is mainly based on DCF estimates, to which a discount is systematically applied.

Roosenboom (2012) shows that investment banks mainly use the comparable multiples approach, the DDM, the DCF and the Economic Value Added (EVA) to a minor extent (19.3\% of cases). Furthermore, in the analysed sample, the multiples approach is present in $87 \%$ of cases and the most popular of all multipliers is the $\mathrm{P} / \mathrm{E}$ ratio, followed by the $\mathrm{P} /$ Cash Flow, the $\mathrm{P} / \mathrm{Sales}$ and, lastly, from asset-side multiples. The study highlights how the choice of one method above another depends on the weight assigned to them according to specific characteristics of the issuer and the general market situation. For example, the underwriter takes into account the dividend payout policy adopted by the company. Moreover, it assigns a lower weight to comparable multiples and to the DCF, preferring the DDM for the valuation of companies that go public when aggregate market returns are low and a large share of profits will be potentially assigned to shareholders in the form of dividends.

Another line of studies subsequently examined the accuracy of the adopted valuation models. Some of these focus on evaluating multiples and provide conflicting results on which type of multiples is the fittest for a more precise estimate (Beatty et al., 1999; Kim \& Ritter, 1999; Liu et al., 2002). Several articles investigate how the choice of comparable companies affects the accuracy of multiples: profitability, growth, and risk are important variables for the selection of companies to be included in the sample (Boatsman \& Baskin 1981; Alford, 1992; Cheng \& McNamara, 2000; Bhojraj \& Lee, 2002). There is some consensus on the fact that multiples based on forecast earnings lead to a higher accuracy than multiples based on actual, realised earnings (Kim \& Ritter, 1999; Liu et al., 2002; Lie \& Lie, 2002). This finding is in line with the studies suggesting that earnings forecasts are based on value information that is not reflected in historical earnings (Tse \& Yaansah, 1999; Liu \& Thomas, 2000; Yee, 2004; Barniv \& Myring, 2006). 
Some studies thereafter compare the accuracy of the evaluation of multiples to that of the DCF method, concluding that both approaches are useful and reliable (Kaplan \& Ruback, 1995; Berkman et al., 2000; Asquith et al., 2005). Penman and Sougiannis (1998) and Francis et al. (2000) compare the DDM evaluation with the DCF evaluation, both reaching the conclusion that the DDM technique produces lower evaluation errors than the DCF. Lundholm \& O'Keefe (2001), however, assert that the superiority of DDM as highlighted in the aforementioned studies is misleading and is due only to inconsistencies in the analysis made by the authors, since the estimates with these methodologies are theoretically equivalent (Ohlson, 1995). In contrast, Bernard (1995) and Walker (1997) claim the superiority of DDM when information is limited.

Deloof et al. (2009) find that the DDM tends to underestimate, leading to evaluations closer to the POP, while the DCF does not generate distortions; however, the absolute prediction errors of the three methods analysed in the study (DDM, DCF, and multiples) do not show statistically significant differences. By using the multiples approach, together with interviews with financial intermediaries, it becomes clear that the latter rely on future estimates of the fundamentals, thus leading to more accurate estimates as already asserted by Kim \& Ritter (1999).

Berkman et al. (2000) compare the accuracy of the DCF and the P/E multiple on a sample of 45 IPOs conducted in New Zealand, finding that both methods perform fairly well with absolute forecast errors of around $20 \%$.

Also in Italy, the analysis of the most relevant literature on the subject highlights immediately how the valuation methods adopted for the listing have changed over time, in correspondence with the evolution of the literature and professional practice.

Notably, there has been a progressive decrease in the use of the mixed equity-income criteria, which up to 1993 were the dominant methodology for the preparation of the expert's certificate (Ferrari \& Iannuzzi 1998; Perrini, 1999), which were replaced by the income methods first and, subsequently, by the DCF together with the market multiples method. The latter, initially used as a control, today is increasingly used in reversible combination with the DCF method, so that, in practice, they tend to be considered "interchangeable" in those two roles.

In line with previous studies, Dell'Acqua et al. (2012), through the collection and examination of the IPO prospectuses of 194 Italian companies listed from 1997 to 2010, show a clear prevalence of financial and market methods in percentage terms. In particular, over fourteen years, the multiples approach was the most frequently used, as both a main and a control method. However, the authors underline the lack of a predefined and standard approach adopted by companies in the pre-IPO pricing: the choice of methodologies, in fact, is based more on the stock market cycle and on the related "valuation opportunism" of the investors, rather than on academic prescriptions. Finally, the results of the survey show that, in the analysed period, market methods, and multiples in particular, replaced the methodologies based on fundamentals as the main criterion, and were, in absolute terms, the most used for company valuation in IPOs.

Ultimately, the review of the most relevant literature suggests a unanimous preference for the DCF, multiples and EVA methodologies in the practice of valuation. Therefore, they are the subject of a subsequent in-depth analysis not only from a theoretical point of view, but also, above all, in terms of stock-exchange listing.

\section{The Valuation Methods Used in IPOs}

As anticipated, the choice of the methodologies aimed at estimating the value of the company being listed should be based on the best valuation practices, according to the specific industry and the peculiar characteristics of the company itself. The review of the main literature shows that DCF, Market Multiples and, even if just to some degree, EVA are the most popular methodologies in the valuation practice.

This review will be followed by an in-depth overview of the main methods that may be implemented to estimate the value of a company being listed and the price of shares that will be issued and it focuses on pricing to take into account the fact that the value of a company could differ considerably during its transformation into a public company (Draho, 2004).

The financial method estimates the value of the company based on its future ability to generate cash flows and, in this perspective, the company capital takes on value as it allows for achieving suitable results to adequately remunerate all the productive factors involved, including the financial resources needed to support the company operations.

The value of the company obtained with the application of the financial method is essentially characterized by three factors:

- Cash flows (available to shareholders or net from operating activities, depending on its levered or unlevered version; 
- The projection period;

- The discount rate.

The cash flows to be estimated for the explicit projection period derive from the preparation of a number of financial forecasts by the business valuator. These would provide the data necessary to calculate the expected cash flow for each of the periods used as a basis for the valuation.

As far as the applied time horizon is concerned, the considerations made for the income model remain valid, i.e. the income framework has to be defined in such a way that at its end the company would have reached a state of substantial equilibrium.

Once the expected cash flows have been determined, a value needs to be attributed to the discount rate. When the financial method adopted is "levered", the rate is provided by the sum of the risk-free rate (multi-year government bonds) and the risk premium (Capital Asset Pricing Model, CAPM). When the preference goes to the unlevered version - generally the most popular in financial models - the discount rate is given by the weighted average cost of capital (known as WACC, Weighted Average Cost of Capital) which can be represented by the following formula (Copeland et al., 1990):

$$
W a c c=K e * \frac{E}{E+D}+K d * \frac{D}{E+D}
$$

$\mathrm{Ke}$ is the cost of equity;

$\mathrm{Kd}$ is the cost of debt;

$\mathrm{E}$ is the shareholders' equity;

$\mathrm{D}$ is the debt.

The best known financial method is the unlevered Discounted Cash Flow (DCF) which in the American financial theory stands as the reference methodology to estimate the company's economic capital. On a practical level, however, there are several barriers, especially if the company being valued does not have the ability to forecast. The future determination of cash flows is, in fact, strictly connected to company strategies and policies, which, in turn, are the result of specific and subjective entrepreneurial choices and are often unpredictable at the time of valuation.

In formula:

$$
W=\sum_{t=1}^{n} \frac{F C_{t}}{\left(1+i_{C l)}\right.}+T V+P F N
$$

Where:

$F C$ are the available cash flows

$i c i$ is the discount rate

$n$ is the number of years of foreseeable duration

$T V$ is the terminal value

NFP is the net financial position

As it can be deduced from the above formula, the application of the DCF is the result of the sum of three main factors (Corbella et al., 2020):

- The operating cash flows that a company will be able to generate in the future, discounted at an actualisation rate equal to the weighted average cost of capital;

- The terminal value of a company, i.e. an estimate of the future value of the company at the end of the explicit projection period;

- The net financial position of a company, expressed in market values and determined with reference to the valuation date.

For the sake of completeness, it should be noted that the estimate of the "invested capital can be characterized by the presence of non-essential assets (Surplus Assets) which contribute to prospective returns independently rather than in combination with other productive factors. When the prospective returns of these investments are dynamic, e.g. are subject to a different degree of risk compared to prospective returns of the company as a whole, it is generally considered preferable to conduct a separate valuation and subsequently to add this value to that of the 
company (the latter net of the components related to surplus assets)".

As it can be deduced from the description of this method, the application of the DCF may lead to significant problems, particularly deriving from the difficulty of making sufficiently reliable forecasts and, therefore, of obtaining realistic prospective financial data.

Moreover, the inherent difficulty in identifying a consistent time horizon, as well as in determining all the data necessary for performing calculations, has to be added: in general terms, these characteristics of partial practical inapplicability make this method quite unusable, especially for IPOs.

The same growth rate "g", used in determining the final value of the company, plays a fundamental role: small fluctuations in its value can have an exceptionally heavy impact on the final result; hence the need to proceed with extreme caution and precision.

For estimating the economic value of the capital, the Multiples Method is widely considered an alternative to those approaches based on flow and stock values. The multiples gained popularity in the $90 \mathrm{~s}$, as before they were considered a technique substantially confined to the world of Investment and Merchant bank (Bini \& Guatri, 2002). The multiples, once widely considered as a simple and quick (and perfunctory) valuation tool to save time and reduce costs, have assumed major importance in business valuation with the introduction of the concept of "probable price".

The multiples estimate the "value of a company on the basis of the transfer prices observed for transactions (total or partial, direct or indirect) concerning the capital of other companies that could be considered comparable to the company being valued" (Musaio, 2009).

More specifically, the method is structured into the following phases:

I) identification of a sample of companies comparable to the one being evaluated;

II) identification of a parameter for expressing performance, capable of "explaining" the differences in market prices for companies comparable to the one being valued;

III) calculation of the multiples of comparable companies, as the ratio between price and performance parameter of each company;

IV) definition of the average value of the multiple;

V) application of the multiple to the same performance parameter of the company being valued.

In essence, a multiple expresses the ratio between the "price" of the capital (P) of a company (x) and an explanatory quantity $(\mathrm{G})$, such as net income, EBIT or operating cash flow, related to the company itself:

$$
M_{X} \frac{P_{X}}{G_{X}}
$$

The definition of an average value of the multiple (Mm) allows for determining the value of a company (y) through the product between the average multiple and the explanatory quantity related to the company being valued:

$$
W_{Y}=G_{Y} \times M_{m}
$$

Multiples can be classified according to a number of criteria: the adopted perspective (levered and unlevered), the type of price (stock multiples and multiples from comparable transactions), the nature of the performance parameter (economic/financial multiples and non-economic/financial multiples), the reference period of the explanatory quantity of the value (historical multiples, trailing multiples, and leading multiples).

Regardless of the adopted type of multiple, the application of this methodology implies two hypotheses:

- Tthe first one consists in assuming that the value of a company varies in direct proportion to the changes in the economic variable chosen as a performance parameter;

- The second one relates to equality in the expected growth rates for cash flows and in the degree of risk.

When both aforementioned hypotheses are satisfied, the multiples approach provides a more objective measure of value if compared with the one obtained with methods based on quantities-flows (income-based and financial methods), since it is based on market expectations both for the company's growth and the discount rate.

However, these two hypotheses may easily not be satisfied: in fact, comparable companies rarely show any equality in the growth rates of cash flows and in the degree of risk. Furthermore, it seems quite simplistic to attribute the role of a performance parameter capable of explaining the difference in value between companies to a single economic variable. 
All the aforesaid, it is clear that the problem of the subjectivity of estimation is only apparently overcome by the multiples approach: in fact, the selection of the sample of comparable companies always entails subjective judgments. Furthermore, the degree of comparability between companies is always limited, either for reasons related to their scope of operations, their size and the consequent risk profile, and, finally, for their different leverage relationships.

To sum up, if on the one hand the multiples approach has several advantages that have contributed to its popularity, such as its simplicity, the lesser amount of data needed for valuations and their immediate and public availability, and the ease of communicating its results, on the other, it presents many criticalities that diminish the significance of the values determined through multiples. It is important to take into account their overly simplifying structure, which completely disregards the examination of data regarding the company being valued, in contrast with other estimation methods; these data are useful to shed light on the underlying values of the companies. What is more, it is always very difficult to find truly comparable companies that may provide reliable terms of comparison.

And it should be noted that, even if the peer companies are successfully identified, further problems would arise in the next phase: the same comparable companies, whose data are processed to identify an average multiple representative of the sector and for the calculation of the respective ratios, may present values that have been already corrupted for various reasons (Draho, 2004).

Furthermore, thanks to the nature of this method, the issuer can easily modify the obtained final values and turn them to his/her own advantage; finally, this procedure acts without considering the actual risk profile for a particular company and, therefore, omits one of the most important aspects of business valuation (Draho, 2004).

The Economic Value Added (EVA) method was not intended as a way of valuing a company in first instance, but as a performance indicator aimed at measuring the ability of an operating company to produce new wealth.

This method, created in the early 90s as a performance evaluation tool by the consulting firm Stern Steward \& Co. which registered the trademark, has gradually become a proper business valuation method that attempts to measure the value produced by a company over the course of a year by comparing the operating profitability with the average cost of invested capital needed for the operation of the company, to quantify whether the return on invested capital is higher or lower than the amount spent for its availability.

Therefore, the basic assumption for the application of this method is the analytical estimate of the invested capital and operating income, appropriately adjusted to sterilise the effects deriving from the accrual basis, in order to achieve a "normalized" result.

In formula:

$$
\mathrm{EVA}=\text { NOPAT }-\left(\mathrm{WACC}^{*} \mathrm{C}\right)
$$

Where:

NOPAT (Net Operating Profit After Taxes) is the normalised net operating income, i.e. the profits available to remunerate all the company's backers;

WACC is the weighted average cost of invested capital, i.e. the weighted arithmetic average between the cost of equity and the credit cost, weighted on the impacts on the financial structures of the company, the equity, and the third parties capitals;

$\mathrm{C}$ is the invested capital, equal to the sum of equity, financial debts, and provisions.

The EVA method is based on the company's ability to provide an extra return on the entire invested capital rather than just on the net equity, thus enhancing the company's ability to create value in the long term.

The calculation procedure of the EVA method is similar to the one used in mixed equity/income-based methods where, in order to quantify the value of the company's economic capital, the goodwill needs to be assessed separately. By the means of this method, however, the goodwill is not calculated as the sum of the discounted expected surpluses, but on a financial basis as the sum of the current values of each EVA.

The formula that expresses the economic value of the company using the EVA method is the following:

$$
W=K \sum_{t=1}^{n} \frac{E V A_{t}}{(1+W A C C)^{t}}+\frac{E V A_{n}}{(W A C C-g)}+\frac{1_{n}}{(1-W A C C)^{n-1}} D
$$

Where:

$\mathrm{W}$ is the economic value of the company

$\mathrm{K}$ is the adjusted net invested capital 
EVA is the increase in economic value

WACC is the weighted average cost of invested capital

$\mathrm{n}$ is the foreseeable duration of the company expressed in years

$\mathrm{g}$ is the growth factor beyond the expected duration

$\mathrm{D}$ is the debt.

This performance indicator, other than being generically used either for the determination of company value, in communications with investors or for planning activities, becomes a fundamental tool in the management of special financing situations.

In our specific case, these are the first pricings, but could also be M\&A or major corporate restructuring.

During the pricing stage of an IPO, EVA ${ }^{\circledR}$ is fundamental because, other than being an indicator of the value actually produced by the company, the actualisation of its flows provide an intermediate quantity, the Market Value Added (MVA) that, added to the CE, provides the total value of the company in terms of EV.

Notably, the MVA stands as the missing link between the price at which the shares of the company will be quoted and the calculation of the EVA®: its determination, in the phases preceding the actual listing on the official markets, allows for estimating the value of a company in the most consistent and adequate manner for its introduction on the stock market (Borsa Italiana, 2004).

\section{Conclusions}

In this study, we have explored the issue of the most appropriate valuation methods for initial public offerings trought the comparison among different valuation methods, proposed in the literature and variously applied in national and international practices highlighting the necessity to pay more attention to valuation mechanisms that drive the pricing of the shares to be listed.

The topic is linked to the ever more pertinent debate on the use of different methods in professional practice: financial experts and analysts tend, in fact, to compare the results according to different estimates.

Whereas, on an international level, the preference goes to the discounting of returns, a widespread professional practice tends to focus on two methodologies in particular, namely the DCF and the market multiples. Also in Italy, the "Instructions Accompanying the Rules of the Markets Organised and Managed by Borsa Italiana SpA" and the "Instructions Accompanying the Rules of the Nuovo Mercato Organised and Managed by Borsa Italiana SpA" (hereinafter, the "Instructions") explicitly require the development of the market multiples and the discounted cash flow methods for listing transactions.

With regard to the former, the Instructions provide some indications on its application, explaining that "the sample of comparable companies must include Italian and European companies where they exist and appropriately divided into groups of homogeneous companies. The document must also specify the criteria used to evaluate the degree of comparability, the multiples considered most appropriate for the comparison and the reference year. With reference to the comparable companies, the document must contain the main figures on their past and prospective profitability and financial situation, a description of the sector they belong to and of the business model adopted, with an indication of the similarities and differences with respect to the issuer".

As stated in the previous sections, the application of the market multiples method requires a number of choices on certain aspects, such as the composition of the sample and the identification of the most suitable indicators that should be included in the valuation document.

With regard to the choice of the reference sample, it is necessary to analyse its differences and similarities with respect to the company being valued, whereas the multiples approach requires identifying the advantages and disadvantages deriving from the use of one indicator over another.

As far as the discounted cash flow method is concerned, it is equally important to point out the assumptions underlying the development of the company's operating cash flows, such as the turnover growth, the trend in operating margins, the level of investments and amortisation, the change in net working capital, as well as the assumptions and methods for calculating the components of the weighted average cost of capital and the perpetual growth rate "g".

Finally, the review of the literature focused on the practical application of the methods adopted in IPOs highlights the need of a greater transparency in disclosing the structure of the valuation process method by the placement agents, in order to protect the potential subscribers of the shares. Hence, for example, the preparation of the document "Le informazioni di natura valutativa nei prospetti informativi nelle operazioni di IPO e nelle operazioni 
di OPV e aumento di capitale di società con titoli non quotati in mercati regolamentati da parte di società con titoli non scambiati in mercati regolamentati" by the OIV Working Group on the proposal of the Italian Companies and Stock Exchange Commission (CONSOB).

Following a brief overview of Italian and European market practices, the document deals with the analysis of valuation methods in IPOs and OPVs, as well as the capital increases of unlisted entities. The text is divided into four chapters and has its roots in the EU Regulation 2017/2109, which replaced and repealed Directive 2003/71/EC, marking a milestone towards the completion of the Union of stock markets. The purpose was, indeed, to protect investors by eliminating the information asymmetries between investors and issuers, as well as to ensure the market efficiency.

\section{References}

Alford, A. W. (1992). The Effect of the Set of Comparable Firms on the Accuracy of the Price Earnings Valuation Method. Journal of Accounting Research, 30(1), 94-108. https://doi.org/10.2307/2491093

Asquith, P., Mikhail, M., \& Au, A. (2005). Information Content of Equity Analyst Reports. Journal of Financial Economics, 75, 245-282. https://doi.org/10.1016/j.jfineco.2004.01.002

Barker, R. (1999). Survey and Market-Based Evidence of Industry-Dependence in Analysts. Preferences between the Dividend Yield and Price-Earnings Ratio Valuation Models. Journal of Business Finance \& Accounting, 26(3-4), 393-418. https://doi.org/10.1111/1468-5957.00261

Barniv, R., \& Myring, M. (2006). An International Analysis of Historical and Forecast Earnings in Accounting-Based Valuation Models. Journal of Business Finance \& Accounting, 33(7-8), 1087-109. https://doi.org/10.1111/j.1468-5957.2006.00596.x

Beatty, R., Riffe, S., \& Thompson, R. (1999). The Method of Comparables and Tax Court Valuations of Private Firms: An Empirical Investigation. Accounting Horizons, 13(3), 177-199. https://doi.org/10.2308/acch.1999.13.3.177

Berkman, H., Bradbury, M., \& Ferguson, J. (2000). The Accuracy of Price-Earnings and Discounted Cash Flow Methods of IPO Equity Valuation. Journal of International Financial Management and Accounting, 11(2), 71-83. https://doi.org/10.1111/1467-646X.00056

Bernard, V. (1995). The Feltham-Ohlson Framework: Implications for Empiricists. Contemporary Accounting Research, 11(2), 733-747. https://doi.org/10.1111/j.1911-3846.1995.tb00463.x

Berrett, C., Di Massa, F., Farina, A., Orsini, E., \& Pellizzoni, E. (2002). Attività, tempi e costi del processo di quotazione: un'analisi del periodo 1999-2001, Milano: Borsa Italiana.

Bhojraj, S., \& Lee, C. (2002). Who is my Peer? A Valuation-Based Approach to the Selection of Comparable Firms. Journal of Accounting Research, 40(2), 407-439. https://doi.org/10.1111/1475-679X.00054

Bini, M., \& Guatri, L. (2002). I moltiplicatori nella valutazione delle aziende, Milano: Università Bocconi.

Block, S. (1999). A Study of Financial Analysts: Practice and Theory. Financial Analysts Journal, 55(4), 86-95. https://doi.org/10.2469/faj.v55.n4.2288

Boatsman, J., \& Baskin, E. (1981). Asset Valuation with Incomplete Markets. The Accounting Review, 56, 38-53. Retrieved from http://www.jstor.org/stable/246461

Borsa Italiana, S. P. A. (2004). Guida alla Valutazione. Retrieved from http://www.borsaitaliana.it

Bradshaw, M. (2002). The Use of Target Prices to Justify Sell-Side Analysts' Stock Recommendations. Accounting Horizons, 16(1), 27-41. https://doi.org/10.2308/acch.2002.16.1.27

Cheng, C. S., \& McNamara, R. (2000). The Valuation Accuracy of the Price-Earnings and Price-Book Benchmark Valuation Models. Review of Quantitative Finance and Accounting, 15, 349-370. https://doi.org/10.1023/A:1012050524545

Copeland, T., Koller, T., \& Murrin, J. (1990). Valuation. Measuring and Managing the Value of Companies. New York: Wiley.

Corbella, S., Liberatore, G., \& Tiscini, R. (2020). Manuale di valutazione d'azienda. Milano: McGrawHilll.

Dell'Acqua, A., Etro, L., \& Gremmo, D. (2012). I metodi di valutazione delle IPO in Italia: analisi ed evoluzione nel periodo 1997-2010. La Valutazione delle Aziende, 62.

Deloof, M., De Maseneire, W., \& Inghelbrecht, K. (2009). How do investment banks value IPOs? Journal of 
Business Finance and Accounting, 36(1-2), 130-160. https://doi.org/10.1111/j.1468-5957.2008.02117.x

Demirakos, E., Strong, N., \& Walker, M. (2004). What Valuation Models Do Analysts Use? Accounting Horizons, 18(4), 221-240. https://doi.org/10.2308/acch.2004.18.4.221

Draho, J. (2004). The IPO Decision: Why and How companies go public. UK: Edward Elgar Publishing Limited.

Ferrari, G. (1992). Il giudizio sulla quotazione di un gruppo di "matricole". In Massari M. (Ed.), Le imprese che possono accedere alla Borsa Valori in Italia. Milano: Il Sole 24 Ore Libri.

Ferrari, G. E., \& Iannuzzi, C. (1998). La valutazione d'azienda e la quotazione in borsa: l'evoluzione delle metodologie valutative adottate ai fini del certificato peritale. La Valutazione Delle Aziende, 8, 69.

Francis, J., Olsson, P., \& Oswald, D. (2000). Comparing the Accuracy and Explainability of Dividend, Free Cash Flow, and Abnormal Earnings Equity Value Estimates. Journal of Accounting Research, 38(1), 45-70, https://doi.org/10.2307/2672922

Giudici, G. (2010). Finanziare le risorse dell'impresa. Milano: Maggioli Editore.

Kaplan, S., \& Ruback, R. (1995). The valuation of cash-flow forecast. Journal of Finance, 50(4), 1059-1093. https://doi.org/10.1111/j.1540-6261.1995.tb04050.x

Kim, M., \& Ritter, J. R. (1999). Valuing IPOs. Journal of Financial Economics, 53, 409-437. https://doi.org/10.1016/S0304-405X(99)00027-6

Lie, E., \& Lie, H. (2002). Multiples Used to Estimate Corporate Value. Financial Analysts Journal, 58(2), 44-54. https://doi.org/10.2469/FAJ.V58.N2.2522

Liu, J. D., \& Thomas, J. (2000). Stock Returns and Accounting Earnings. Journal of Accounting Research, 38, 71 101. https://doi.org/10.2307/2672923

Liu, J., Nissim, D., \& Thomas, J. (2002). Equity valuation using multiples. Journal of Accounting Research, 40, 35-172. https://doi.org/10.1111/1475-679X.00042

Lundholm, R., \& O'Keefe, T. (2001). Reconciling Value Estimates from the Discounted Cash Flow Model and the Residual Income Model. Contemporary Accounting Research, 18(2), 311-335. https://doi.org/10.1506/W13B-K4BT-455N-TTR2

Musaio, A. (2009). Il capitale d'impresa. Configurazione e valutazione. In Montrone A., \& Musaio A. (Eds.), Capitale e operazioni straordinarie. Milano: McGraw-Hill.

Ohlson, J. (1995). Earnings, Book Values, and Dividends in Equity Valuation. Contemporary Accounting Research, 11(2), 661-997. https://doi.org/10.1111/j.1911-3846.1995.tb00461.x

OIV- Organismo Italiano di Valutazione. (2018). Le informazioni di natura valutativa nei prospetti relativi alle operazioni di IPO, di OPV e di aumento di capitale da parte di società con titoli non scambiati in mercati regolamentati. Discussion Paper, n. 01.

Pagano, M., Panetta, F., \& Zingales, L. (1998). Whay do companies go public? An empirical analysis. The Journal of Finance, 53(1), 27-64. https://doi.org/10.1111/0022-1082.25448

Penman, S. H., \& Sougiannis, T. (1998). A Comparison of Dividend, Cash Flow, and Earnings Approaches to Equity Valuation. Contemporary Accounting Research, 15(3), 343-383. https://doi.org/10.1111/j.19113846.1998.tb00564.x

Perrini, F. (1999). Le nuove quotazioni alla Borsa Italiana: Evidenze empiriche delle PMI. Milano: Egea.

Previts, G., Bricker, R., Robinson, T., \& Young, S. (1994). A Content Analysis of Sell-Side Financial Analyst Company Reports. Accounting Horizons, 8, 55-70.

Roosenboom, P. (2012). Valuing and Pricing IPOs. Journal of Banking \& Finance, 36(6), 1653-1664. https://doi.org/10.1016/j.jbankfin.2012.01.009

Tse, S., \& Yaansah, R. (1999). An Analysis of Historical and Future-Oriented Information in Accounting-Based Security Valuation Models. Contemporary Accounting Research, 16(2), 347-380. https://doi.org/10.1111/j.1911-3846.1999.tb00586.x

Walker, M. (1997). Clean Surplus Accounting Models and Market-Based Accounting Research: A Review. Accounting and Business Research, 27(4), 341-355. https://doi.org/10.1080/00014788.1997.9729559

Yap, C. (1997). Users' Perceptions of the Need for Cash Flow Statements - Australian Evidence. European Accounting Review, 6(4), 653-672. https://doi.org/10.1080/09638189700000006 
Yee, K. (2004). Forward versus Trailing Earnings in Equity Valuation. Review of Accounting Studies, 9, 301-329. https://doi.org/10.1023/B:RAST.0000028192.03130.df

\section{Copyrights}

Copyright for this article is retained by the author(s), with first publication rights granted to the journal.

This is an open-access article distributed under the terms and conditions of the Creative Commons Attribution license (http://creativecommons.org/licenses/by/4.0/). 